Translating Property 
The publisher gratefully acknowledges the generous contribution to this book provided by the General Endowment Fund of the University of California Press Associates. 


\section{Translating Property}

The Maxwell Land Grant and the Conflict over Land in the American West, 1840-1900

MARÍA E. MONTOYA

University of California Press

BERKELEY LOS ANGELES LONDON 
University of California Press

Berkeley and Los Angeles, California

University of California Press, Ltd.

London, England

(C) 2002 by The Regents of the University of California

Library of Congress Cataloging-in-Publication Data

Montoya, María E., 1964-.

Translating property : the Maxwell Land Grant and the conflict over land in the American West, 1840-1900 / María E. Montoya.

p. $\mathrm{cm}$.

Includes bibliographical references and index.

ISBN 0-520-22744-1 (alk. paper)

1. Maxwell Land Grant (N.M. and Colo.)-History. 2. New

Mexico-History-1848-. 3. New Mexico-Race relations.

4. Land tenure-New Mexico-History-19th century. I. Title.

F802.M38 M66 2002

978.9- dc21

2001027677

Manufactured in the United States of America

$\begin{array}{llllllllll}11 & 10 & 09 & 08 & 07 & 06 & 05 & 04 & 03 & 02\end{array}$

$\begin{array}{llllllllll}10 & 9 & 8 & 7 & 6 & 5 & 4 & 3 & 2 & 1\end{array}$

The paper used in this publication meets the minimum requirements of ANSI/NISO Z39.48-1992 (R 1997) (Permanence of Paper). @ 
For my dad,

Frederick D. Montoya,

1936-1997 
This page intentionally left blank 